\title{
Phytochemical Analysis and Anticancer Activity of Ethanolic Extract Against A549 Human Lung Cancer Cell Line Azadirachta Indica
}

\section{Azhagu Madhavan S1, *}

${ }^{1}$ PG \& Research Deparment of Zoology \& Biotechnology, A Veeriya Vandayar Memorial Sri Pushpam College, (Autonomous) Poondi, Thanjavur, 613503, Tamil Nadu, India.

\begin{tabular}{|c|c|c|}
\hline Received: 01.02 .20201 & - $\quad$ Accepted: 15.03.2021 & $\bullet$ \\
\hline
\end{tabular}

\begin{abstract}
Azadirachta indica phytochemicals are found to be effective against malignant growth and hostile to bacterial properties. In the specific examination, the coupling proficiency of five mixes that are available in the Azadirachta indica with all the eleven proteins through in silico techniques was completed. Plant removes harmful compound instigated injury by expanding the body's degrees of cell reinforcement particles. For example, they affect the glutathione, and improving the action of cancer prevention agent chemicals. About 549 cells treated with Azadirachta indica ethanolic separated in various hours $(6,12,24$ and 36 hours). After 36 hours, the cells development was controlled. There are re-established interests in home grown based meds to hinder the results of manufactured medications, Azadirachta Indica L. A leaf contains phytochemical intensifies that has all freer revolutionary rummaging just as anticancer exercises.
\end{abstract}

KEYWORDS: Azadirachta Indica, Human cancer cell line A549, Phytomedicine.

\section{INTRODUCTION}

\subsection{Natural antibiotic properties of plant secondary metabolites}

A local herb known as neem (semambu) or its logical name Azadirachta indica has been utilized widely in customary treatment because of its restorative properties. Neem leaves have been utilized generally for treating a few epidermal dysfunctions, such as skin inflammation, psoriasis, and skin break out [1]. In the assessment, the coupling viability of five blends that are accessible in the acalypha indica with all the eleven proteins through in silico procedures was finished. Gas chromatography ("GC") and Mass Spectrometry ("MS") make a successful blend for synthetic investigation. Gas chromatography (GC) is perhaps the most broadly utilized method [2-5]. Thus, an endeavour has been made to both assess the productivity of different natural solvents and antibacterial movement and distinguish the substance [7,17]. Segments by GC-MS investigation of rough bark were separated from the Azadirachta indica against chosen bacterial strains [8-11]. Neem is rich in cancer prevention agents, and it assists boosting invulnerable reaction in the tissues of influenced skin region [12-17]. It comprises of bioactive mixes for antibacterial, antifungal, and anticancer exercises [18]. In this investigation, neem leaves remove was utilized in creating natural neem cleanser as a solution for restoring skin issues.

\footnotetext{
* Corresponding Author: mathavan062@gmail.com
} 


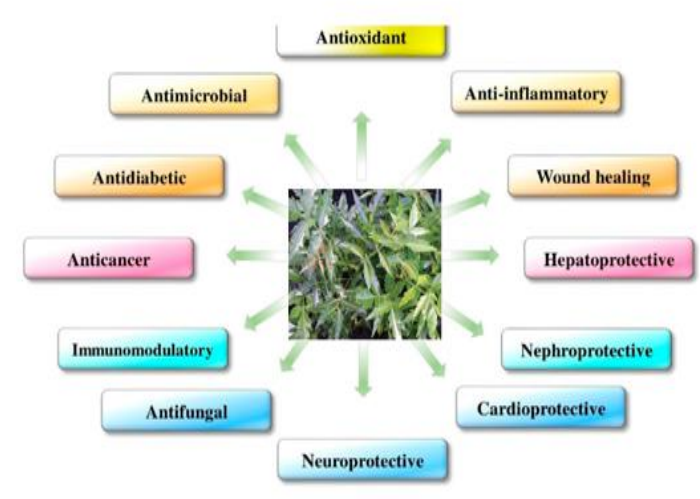

Figure 1. Azadirachta indica medicinal values

\subsection{Phytochemicals shows antioxidant activities}

The free revolutionary present of our body is responsible for the age of numerous illnesses. One can keep himself from illnesses by activity of free extremists simply by deactivation of free revolutionary [19]. Cancer prevention agents have property to stop the movement of free extremists before its activity to words the organic cell of human body [20-23]. It has been accounted for that the oil ether, methanol, and watery concentrates of the leaves of Azadirachta indica were screened for their enemy of microbial movement utilizing the cup plate agar dissemination technique [25]. They were tried against six microscopic organisms, two Grampositive microorganisms (Bacillus subtilis and Staphylococcus aureus) and four Gram-negative microbes (Escherichia coli, Proteusvulgaris, Pseudomonas aeruginosa and Salmonella typhi) [26-29]. The powerlessness of the microorganisms to the concentrates of this plant was contrasted and one another and with chose anti-infection agents [30]. Methanol concentrations of Azadirachta indica showed articulated movement against bacillus subtilis (28mm). Azadirachta indica has a place with the family Meliaceae generally called as neem (English), Vempu (Tamil) and is found all through India [31]. A medium to enormous estimated tree, grows up to 50 feet $(15 \mathrm{~m})$ tall and lives for 200 years. It has been recommended that ethanol extricates from plants utilized.

\subsection{Activity against malaria}

The antimalarial movements of the tablet suspension of the bark and leaf of Azadirachta indica were assessed. On plasmodium yoelli nigeriensis contaminated mice. [32] "The tablet suspensions showed high prophylactic, moderate suppressive and a negligible therapeutic schizonticidal impact [33]. The tablet suspensions from the leaf and bark at a grouping of $800 \mathrm{mg} / \mathrm{kg}$ and chloroquine at a centralization of $62.5 \mathrm{mg} / \mathrm{kg}$ body weight delivered normal rate (\%) parasitaemia of $79.6 \%, 68.2 \%$ and $99.5 \%$ for leaf, bark and chloroquine, individually, in chemosuppression. Likewise, in the prophylactic treatment, the tablet suspensions at $800 \mathrm{mg} / \mathrm{kg}$ and pyrimethamine at a convergence of $0.35 \mathrm{mg} / \mathrm{kg}$ gave a normal parasitaemia decrease of $75.3 \%, 65.6 \%$ and $98.3 \%$ for the leaf, bark and pyrimethamine, individually" [34]. Convenient was the sign of reasonable valuable impact. In the only remaining century, huge advancement in bio-clinical science has vanquished numerous sicknesses anyway disease stays vague particularly from a restorative viewpoint [35]. Malignancy is yet the most widely recognized reason for death from sickness after myocardial dead tissue. Tumour or neoplasm is generally characterized as a development of an irregular mass of tissue because of uncontrolled cell development, while disease is the term of every single dangerous tumour [27]. 
Numerous logical investigations that zeroed in on the pharmacological action of bio-dynamic parts from plants lately increment the premium from academic local area to distinguish some novel diseases suppressant. Natural focuses of phytochemicals in mammalian cells were found to metastases [22]. Moreover, epidemiological examinations recommend that the day by day admission of specific phytochemicals can lessen the frequency of a few sorts of malignant growths [17]. The primary framework in the body for breathing is respiratory framework. The respiratory framework incorporates the nose, mouth, (windpipe) and aviation routes to every lung. The aviation routes to every lung are called huge aviation routes (bronchi) and little aviation routes (bronchioles). Cellular breakdown in the lungs is the second most regular disease in the two people on the planet. It represents about $14 \%$ of all new diseases in the two people. For smokers, the danger of cellular breakdown in the lungs is much higher than in non-smokers [11]. Cellular breakdown in the lungs is a malignancy that begins in the lungs. Cellular breakdowns in the lungs are thought to create over numerous years. There are two significant sorts of cellular breakdown in the lungs. On the off chance that a cellular breakdown in the lungs has qualities of the two sorts, it is known as a blended little cell/huge cell malignancy which this is not normal. Uranium is principle malignancy causing specialist found in rocks and soil [13]. As it rots, a gas called radon is freed and gets blended into air and water. Diggers of uranium have high danger of creating cellular breakdown in the lungs. A few investigations of radon found at homes have indicated the impact in causing cellular breakdown in the lungs, while different examinations have not. The danger for cellular breakdown in the lungs may rely upon how much level of radon gets presented to a person. The plant fabricated materials are appointed fundamental or discretionary metabolites [19]. Fundamental metabolites are extensively passed on in nature, occurring in some designs in essentially all living creatures. In higher plants such blends are as often as possible stuffed in seeds and vegetative amassing organs and are needed for physiological headway considering their part in fundamental cell assimilation. Fundamental metabolites got from higher plants for business use are high volume-low worth mass manufactured mixes (for instance vegetable oils, unsaturated fats, starches, etc).

\section{2. MATERIAL METHODS:}

\subsection{Plant Collection}

The fresh leaves of Azadirachta indica were collected from Saliyamangalam, Thanjavur District, Tamil Nadu, India.

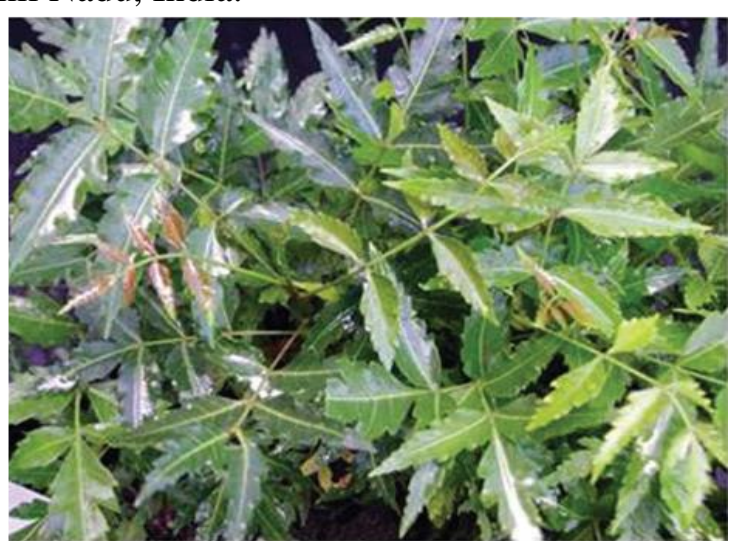

Figure 2. Map 1: Study area

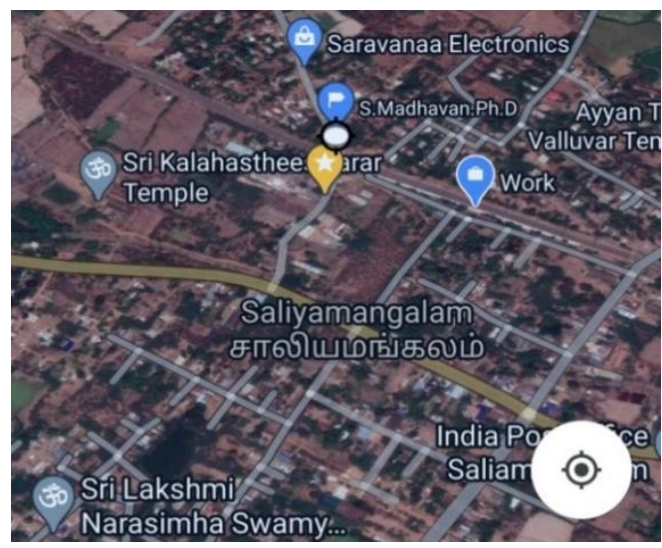

Figure:3. Azadirachta indica 


\subsection{Plant material}

The Azadirachta indica leaves were dried up under shade, specifically diminished to a decently crude powder, and put away in golden hued sealed shut holders. The crude type of the medication was utilized for the declaration of physicochemical boundaries like dampness content, debris esteems, expanding file, frothing record, unfamiliar natural issue, extractive qualities, and fluorescence analysis.

\subsection{Phytochemical Studies}

Secondary metabolites in the present studies were carried out on the plant sample revealed the presence of medicinally active constituents. Beneficial drugs improve patient health.

\subsection{Preparation of extracts}

The powdered plant samples of leaves $(100 \mathrm{~g})$ were used for successive solvent extraction $(500 \mathrm{ml})$ with increasing order of polarities like ethanol and methanol. At that point, it is kept in an orbital shaker at 190-220rpm for 48 hours. The supernatant was collected, filtered through Whatman No.1. Filter paper and the extract were concentrated by a Rotary flask evaporator at a specific temperature that was used based on the solvent system. The acquired dried concentration was then precisely gauged, put away in little vials at $-20^{\circ} \mathrm{C}$ and utilized for the accompanying examinations.

\section{5. phytochemical screening}

The preliminary phytochemical evaluation was accepted out by using standard procedure [8-9].

\subsection{Culturing of cell lines}

The Vero and human lung cancer cells (A549) were obtained from Kings Institute of Preventive Medicine and Research, Guindy, Chennai. The cells were grown in 96-well tissue culture (TC) plate in Dulbecco's Minimum Essential Medium (MEM) with Trypsin-phosphate-verseneglucose (TPVG) solution, 10\% New Born Calf Serum (NBCS) (Gibco-Invitrogen), $100 \mathrm{U} / \mathrm{mL}$ of penicillin (GibcoInvitrogen) and $100 \mu \mathrm{g} / \mathrm{mL}$ of streptomycin (Gibco-Invitrogen). The cells were incubated in $\mathrm{CO} 2$ incubator (Haier Electric Co., Ltd.,) at $37 \mathrm{oC}$ in $95 \%$ humidified atmosphere enriched by $5 \% \mathrm{CO} 2$ and sub-cultured every 3-4 days once.

\subsection{MTT cell viability assays}

The MTT assay was done using the methodology of monolayer of cell culture that was trypsinized. The cell count was adjusted to $1.0 \times 105$ cells $/ \mathrm{ml}$ using growth medium. To each of the 96 well microtitre plate, $0.1 \mathrm{ml}$ of the diluted cell suspension (approximately 10,000 cells /well) was added. After 24 hours, when a partial monolayer was formed, the supernatant was flicked off, the monolayer was washed once and $100 \mu \mathrm{l}$ of leaves of Azadirachta indica leaves ethanolic extract with different concentrations $(100,200,250,500$ and $1000 \mu \mathrm{g} / \mathrm{ml})$ was added to each one. The plates were then incubated at $37 \mathrm{oC}$ for 3 days in $5 \% \mathrm{CO}_{2}$ atmosphere, and microscopically examined at the end of 6 , 12, 24 and 36 hours for recording the result. After 72 hours, the test solutions in the wells were discarded and $50 \mu 1$ of MTT in HBSS-PR was added to each well. The plates were gently shaken and incubated for 3 hours at $37 \mathrm{oC}$ in $5 \% \mathrm{CO}_{2}$ atmosphere. The supernatant was removed and $50 \mu \mathrm{l}$ of propanol was added and therefore the plates were gently shaken to solubilize the formed formazan. 
The absorbance was measured using a microplate reader at the wavelength of $540 \mathrm{~nm}$. The percentage growth inhibition was calculated using the formula given below:

$\%$ Cytotoxicity $=(1-$ Abs test $/$ Abs Control $) \times 100$

\section{Statistical analysis}

.Statistical analysis was performed by one-way analysis of variance (ANOVA) followed by Duncan's multiple range test (DMRT) using Software Package for the Social Science (SPSS) software package version 15.00. Results were expressed as Mean \pm Standard Deviation for $\mathrm{p}$ values $<0.05$ were considered significant for analysis of percent inhibition of cell growth.

\section{RESULTS AND DISCUSSION}

Plants and their derivative may be measured as good sources of natural phytochemicals for medicinal uses. The result of the preliminary phytochemical analysis of this present study may give credence to its ethno medicinal tradition. Saponin is used as a mild detergent and in intracellular his to chemistry staining to permit antibody access to intracellular proteins [18]. In medicine, it is used in hypercholesterolemia, hyperglycaemia, antioxidant, anticancer, anti-inflammatory, and weight loss among others. It is also known to contain antimicrobial properties.

Table 1. Qualitative analysis of Phytochemicals analysis Azadirachta indica leaves extract

\begin{tabular}{|c|c|c|c|c|}
\hline S. & & $\begin{array}{c}\text { Analysed } \\
\text { Phytochemicals } \\
\text { foctor }\end{array}$ & Ethanol & Methanol \\
\hline 1. & Tannin & ++ & + \\
\hline 2. & Phlobatannins & - & + \\
\hline 3. & Saponin & + & + \\
\hline 4. & Flavonoids & ++ & + \\
\hline 5. & Steroids & ++ & - \\
\hline 6. & Terpenoids & + & + \\
\hline 7. & & Triterpenoids & + & + \\
\hline 8. & & Alkaloids & ++ & + \\
\hline 9. & & Carbohydrate & + & - \\
\hline 10. & & Protein & ++ & - \\
\hline 11. & & Anthraquinone & - & - \\
\hline 12. & & Polyphenol & ++ & + \\
\hline 13. & & Glycoside & + & - \\
\hline & & & & + \\
\hline & & & & + \\
\hline
\end{tabular}

Indications: "+" means positive activity, "_" means negative activity 


\subsection{Preliminary phytochemical screening}

India is most likely the greatest creator of restorative flavours on the planet [12]. While the mechanism of action possessed by tannins is by disrupting the worm's negative ion body charge into positive ions (protonization). It attracts positive worm body proteins in the gastrointestinal tract, thus disrupting the metabolism and homeostasis of the worm's body.

A natural cleanser has been delivered effectively from neem leaves separate in this examination. The outcomes from the physicochemical properties of the neem cleanser arranged were contrasted with neem seed oil cleanser and business neem cleanser. The outcomes suggest that the neem cleanser created is reasonable for human skin. In addition, it is an item advancement of a characteristic sedated cleanser created from neem leaves remove that is liberated from synthetic substances, for example, sodium sulphate (SLS), fake colorant, and fake scent, hence can be a reasonable elective treatment for buyers who have skin issues [15]. However, there are numerous reports on the in vitro investigation of these mixes and its restorative and harmful properties, there are no in silico examines that foresee the authoritative and dynamic districts particularly with these proteins [6]. Our investigation is an endeavour to anticipate the coupling site and the coupling deposits. Nonetheless, approval of our outcomes through invivo and invitro tests and furthermore with creature models will edify trust for the future improvement of additional powerful medications for the treating of pharmacological significance of contain the properties, for example, antibacterial enemy of diabetic and pain relieving.

\subsection{Anticancer Activity on A549 Cell Lines}

The Azadirachta indica ethanolic extract showed the anticancer activity against A549 cell line in a dose dependant manner. A549 cells treated with Azadirachta indica ethanolic extract in different hours $(6,12,24$ and 36 hours) after 36 hours the cells growth are controlled. The Azadirachta indica ethanolic extract showed a maximum inhibition of $68 \%$ at $500 \mu \mathrm{g} / \mathrm{ml}$ against A549 lung cancer cells [11]. The minimum inhibition of $12 \%$ was recorded at $100 \mu \mathrm{g} / \mathrm{ml}$ concentration. The A549 cells normally contain a polygonal shape and expanse similar [9]. The Azadirachta indica ethanolic extract showed a maximum inhibition of $68 \%$ at $500 \mu \mathrm{g} / \mathrm{ml}$ against A549 lung cancer cells. The minimum inhibition of $12 \%$ was recorded at $50 \mu \mathrm{g} / \mathrm{ml}$ concentration. Herbal mediated silver nanoparticles playing important role to create recyclable, cost effective and stable nanoparticles [12]. The investigation on union of silver nanoparticles utilizing different plant removes found that it is supplementary secure and better in malignant growth treatment. However, more plants are not investigated for the combination of nanoparticles and their applications in drug businesses. 

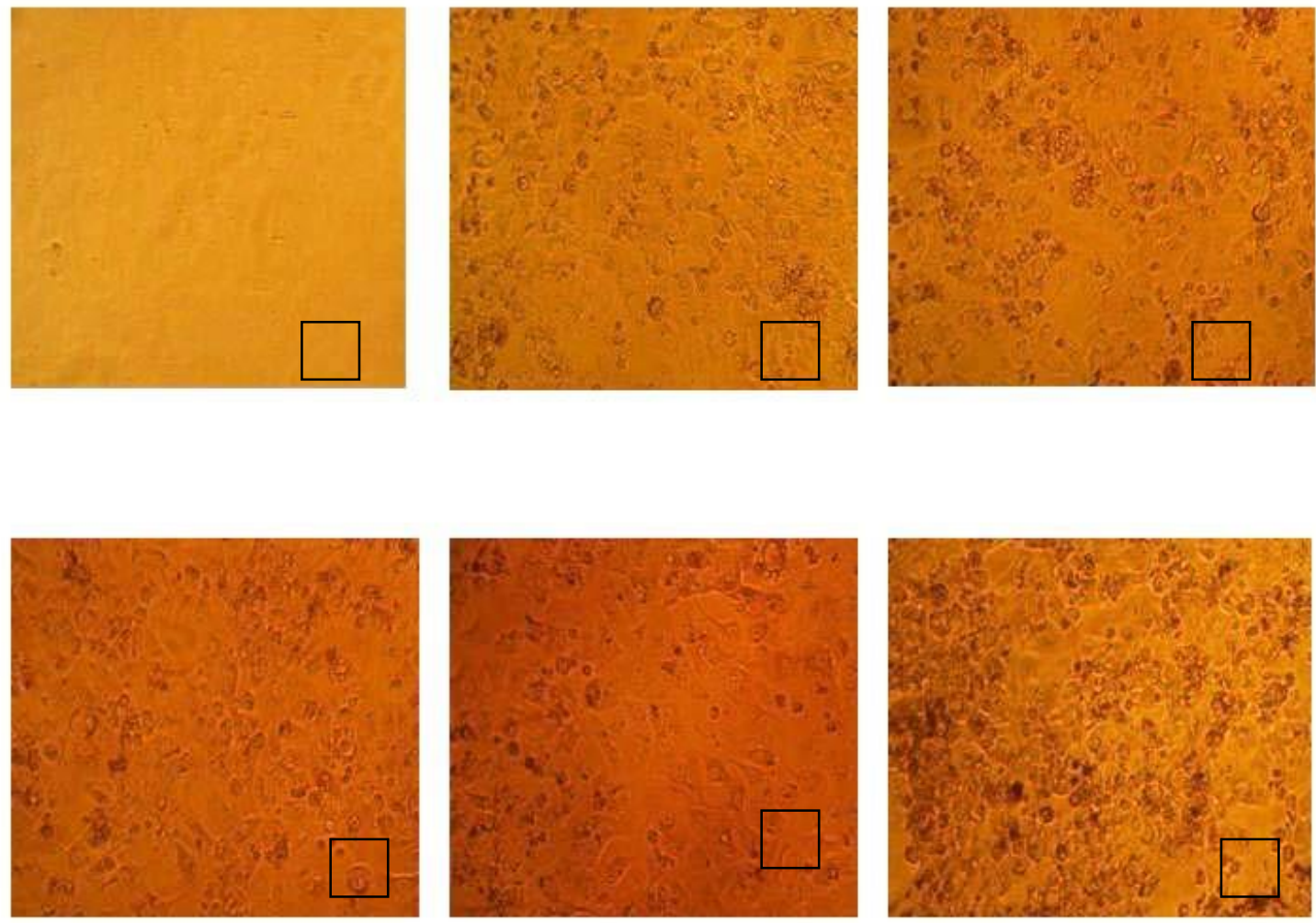

A. control, B. $100 \mu \mathrm{g} / \mathrm{ml}$, C. $200 \mu \mathrm{g} / \mathrm{ml}$, D. $250 \mu \mathrm{g} / \mathrm{ml}$, E. $500 \mu \mathrm{g} / \mathrm{ml}$, F. $1000 \mu \mathrm{g} / \mathrm{ml}$.

The cells of living beings can be considered as miniature synthetic reactors creating huge number of substance mixes through metabolic responses. Ayurvedic arrangement of medication in India and is utilized in relieving different sicknesses like stomach issues, gastric ulcers and to animate craving [14]. The cytotoxic properties were assessed on malignant growth cells of breast cancer(MCF-7), cellular breakdown in the lungs (A-549) cell lines and contrast and ordinary cell line L-6 (Rat, Normal muscle) utilizing MTT colorimetric test for 24,48 and $72 \mathrm{hrs}$. There is no orderly work that has been embraced on this plant and this is the principal report of the phytochemical screening, cell reinforcement and anticancer exercises evoked by saponin from Decalepis hamiltonii [14]. Combination of home-grown intervened silver nanoparticles gives controlled and focusing on activity of medication, which can likewise defeat the issues related to traditional disease medicines. The current investigation has been detailed to comprehend the phytochemical screening, in vitro cell reinforcement and anticancer properties evoked by saponin from foundations of Decalepis hamiltonii.

\section{CONCLUSION}

Allopathic medicine is potential sources of antiviral, antitumor and antimicrobial agents. The plausible instrument in the phone demise or apoptosis is interfaced with the phone film proteins. It makes the phone release its constituents lastly driving passing or possibly it can connect with the DNA or cell declining pathways and controlling the pathways driving or scenery off the cell demise pathways. The presence of such assortment of phytochemicals might be credited to the therapeutic qualities of this plant Azadirachta indica. The consequences of this investigation uphold the conventional utilization of Azadirachta indica bark as an antibacterial specialist. In a few reports, 
these mixes can be answerable for the preventative properties credited to this plant in famous and conventional medication.

\section{ACKNOWLEDGEMENT}

The author is very grateful to the Secretary and Correspondent and the Principal of A.V.V.M. Sri Pushpam College (Autonomous), Poondi-613 503, Thanjavur (Dt), for providing the excellent infrastructure and necessary facilities to carry out my research work successfully.

\section{CONFLICT OF INTEREST}

The authors have declared that there is no conflict of interest.

\section{SOURCE/S OF FUNDING}

No source of funding.

\section{REFERENCES}

[1] .Zong, A. Cao, H. and Wang, F. (2012). Anticancer polysaccharides from natural resources: a review of recent research. Carbohydrate Polymers. 90(4), 1395-1410.

[2] Efferth, T. and Koch, E. (2011). Complex interactions between Phytochemicals. The Multi-Target Therapeutic concept of Phytotherapy. Current Drug Targets. 12(1), 122-132.

[3] Chandra Mohan S, Dinakar S, Anand T, Elayaraja R, SathiyaPriya B (2012). Phytochemical, GC-MS analysis and Antibacterial activity of a Medicinal Plant Acalypha indica Int. J. PharmTech Res.,4(3).

[4] Sushmitha H. S, Balasubramanian Sathyamurthy. (2018). In Silico drug designing studies on Dengue Virus NS2BNS3 Proteasell, Indo American Journal of Pharmaceutical Sciences,; 5(8): 7784 - 7790.

[5] Meena MK, Singh N, Patni V. Determination of bioactive components of the leaves of Cocculus hirsutus (L.) diels using GC-MS analysis. Int. J. Pharm. Pharm. Sci. 2014;6: 327-329.

[6] Kawatu CB, Mongi J. Test on the Effect of Ethanol Extract of Anting-anting Leaf (Acalypha indica L.) on Blood Sugar Levels of Male White Mouse Wistar (Rattus novergicus) (Uji Efek Ekstrak Etanol Daun Anting-Anting (Acalypha indica L.) Terhadap Kadar Gula Darah Tikus Putih Jantan Galur Wistar (Rattus novergicus). Pharmacon. 2013;81-85.

[7] Al Akeel, R., Mateen, A., Janardhan, K., \& Gupta, V. C. (2017). Analysis of anti-bacterial and antioxidative activity of Azadirachta indica bark using various solvents extracts. Saudi Journal of Biological Sciences, 24(1), 11-14.

[8] Mandokhail, F., Jamil, N., Riaz, M., Masood, Z., Ahmed, S., Asif, B., Sham-Ud-Din, G., Noor, G., Rehman, N., Zahid, S., Bano, A., Dil Murad, F., Shakeel, D., \& Mengal, F. (2015). Study of physica; and chemical properties of local neem (azadirachta indica) soap with branded soaping relation to their impact on skin. Am-Euras. J. Toxicol. Sci., 7(4), 239-242.

[9] Francine, U., Jeannette, U. \& Pierre, R.J. (2015) Assessment of antibacterial activity of Neem plant (Azadirachta indica) on Staphylococcus aureus and Escherichia. Journal of Medicinal Plants Studies, 3(4), 85-91.

[10] Hossain, M. A., Al-Toubi, W. A., Al-Sabahi, J. N., Weli, A. M., \& Al-Riyami, Q. A. (2013). Identification and characterization of chemical compounds in different crude extracts from leaves of Omani neem. Journal of Taibah University for Science, 7, 181-188.

[11] Krishnasamyet, A., Sundaresan, M., \& Velan, P. (2015). Rapid phytosynthesis of nano-sized titanium using leaf extract of Azadirachta indica. International Journal of Chem Tech Research, 8(4), 2047-2052. 
[12] Lakshmi, T., Krishnan, V., Rajendran, R., \& Madhusudhanan, N. (2015). Azadirachta indica: A herbal panacea in dentistry-An update. Pharmacognosy Reviews, 9(17), 41.

[13] Mak-Mensah, E. E., \& Firempong, C. K. (2011). Chemical characteristics of toilet soap prepared from neem (Azadirachta indica A. Juss) seed oil. Asian J Plant Sci Res, 1(4), 1-7.

[14] Kumar SV, Kumar C, Vardhan A. (2013;). Hepatoprotective activity of Acalypha indica Linn against thioacetamide-induced toxicity. Int J Pharm Pharm Sci 5:3-6.

[15] Lee EJ, Oh H, Kang BG, Kang MK, Kim DY, Lee JY, (2018). Lipid-lowering effects of medium-chain triglyceride-enriched coconut oil in combination with licorice extracts in experimental hyperlipidemic mice. J Agric Food Chem. 66:10447-57.

[16] Chekuri S, Panjala S, Anupalli RR (2017). Cytotoxic activity of Acalypha indica L. hexane extract on breast cancer cell lines (MCF-7). J Phytopharmacol; 6(5):264-268.

[17] Joshi SM, De Britto S, Jogaiah S, Ito SI. (2019). Mycogenic selenium nanoparticles as potential new generation broad spectrum antifungal molecules. Biomolecules; 9:419.

[18] Asghari-Paskiabi F, Imani M, Rafii-Tabar H, Razzaghi- Abyaneh M. (2019). Physicochemical properties, antifungal activity and cytotoxicity of selenium sulfide nanoparticles green synthesized by Saccharomyces cerevisiae. Biochem Biophys Res Commun; 516:1078-84.

[19] Menon S, Agarwal H, Rajeshkumar S, Rosy PJ, Shanmugam VK (2020). Investigating the antimicrobial activities of the biosynthesized selenium nanoparticles and its statistical analysis. BioNanoScience.

[20] Menon S, Devi KS, Santhiya R, Rajeshkumar S, Kumar V. (2018). Selenium nanoparticles: A potent chemotherapeutic agent and an elucidation of its mechanism. Colloids Surf B Biointerfaces; 170:280-92.

[21] Murugesan G, Nagaraj K, Sunmathi D, Subramani K. (2019). Methods involved in the synthesis of selenium nanoparticles and their different applications-a review. Eur J Biomed; 6:189-94.

[22] SK. Umate and VR. (2018). Marathe. Nutraceutical evaluation of Acalypha indica L. - A potential wild edible plant. International Journal of Green Pharmacy, Vol. 12 (3 Suppl.), 510-517.

[23] Teklani PWNN, and Perera BGK. (2016). "The important biological activities and phytochemistry of Acalypha indica." International Journal of Research in Pharmacy and Science 6.1: 30-35.

[24] Prem KK, Nirmala B, and Rani AR. (2016): “Antimicrobial, Antioxidant Activity and Phytochemical Screening of Acalypha indica Crude Leaf Extract.” International Journal of Pharmaceutical and Clinical Research 8.6 ;583-588.

[25] Nurul NMN, Norazlanshah H, Muhammad I, Mashita M, and Ayob MK. (2016): "Preliminary studies on acalypha indica: proximate analysis and phytochemical screening." International Journal of Pharmacy and Pharmaceutical Sciences $8.3 ; 406-408$.

[26] Chandrasekar R, and Sivagami B. (2016): “Alternative treatment for psoriasis - A review.” International Journal of Research and Development in Pharmacy and Life Sciences 5.4 ;2188-2197.

[27] Rajkiran Reddy Banala, Satish Kumar Vemuri, Gurava Reddy A.V., Subbaiah G.P.V., (2017): Aqueous extract of Acalypha indica leaves for the treatment of Psoriasis: In-vitro studies. International Journal of Bioassays 6.04 ;5360-5364.

[28] Mohan C, Dinakar S, Anand T. (2012). Phytochemical, GC-MS analysis and antibacterial activity of a medicinal plant Acalypha indica. Int J PharmTech Res; 4:1050-4.

[29] Eid A, Jaradat N, Elmarzugi N, (2017). A Review of chemical constituents and traditional usage of Neem plant ( Azadirachta indica ), Palest. Med. Pharm. J. $2 ; 75-81$.

[30] Ojewumi M.E., Owolabi R.U. (2012). The effectiveness of the extract of 'Hyptis suaveolens' leave (a specie of effinrin) in repelling mosquito, Transnatl. J. Sci. Technol. 2 (8) ;79-87.

[31] Ogunlana O.O., Ogunlana O.E, Ntube C.A, Olagunju J.A. Akindahunsi, A. A ., Phytochemical Screening and in vivo antioxidant activity of Ethanolic extract of caesalpinia bonduc (L.) Roxb, Glob. Res. J. Pharm. Sci. 1 (1) (September 2012) 1-4

[32] Pan S.-Y., (2013). New perspectives on how to discover drugs from herbal medicines: CAM's outstanding contribution to modern therapeutics, Evi- dence-Based Complement. Altern. Med. $2013 ; 1-25$.

[33] Ojewumi M.E., Adedokun S.O., Omodara O.J. (2017) , Oyeniyi E.A, Taiwo O.S., Ojewumi E.O, Phytochemical and antimicrobial activities of the leaf oil extract of Mentha spicata and its efficacy in repelling mosquito, Int. J. Pharm. Res. Allied Sci. 6 (4) ;17-27. 
[34] Eid A, Jaradat N., Elmarzugi N. (2017), A Review of chemical constituents and traditional usage of Neem plant ( Azadirachta indica), Palest. Med. Pharm. J. 2;75-81.

[35] Babatunde D.E, Otusemade G.O., Ojewumi M.E, Agboola K.D. Akinlabu,. Oyeniyi E (2019), Antimicrobial activity and phytochemical screening of neem leaves and lemon grass essential oil extracts, Int. J. Mech. Eng. Technol. 10 (02) (February). 